\title{
Polysaccharopeptide enhances the anticancer activity of doxorubicin and etoposide on human breast cancer cells ZR-75-30
}

\author{
JENNIFER MAN-FAN WAN, WAI-HUNG SIT and JIMMY CHUN-YU LOUIE \\ School of Biological Sciences, The University of Hong Kong, Pokfulam Road, Hong Kong SAR, P.R. China
}

Received August 13, 2007; Accepted October 12, 2007

\begin{abstract}
In search of natural bioactive microbial compounds with adjuvant properties, we have previously showed that the polysaccharopeptide (PSP), isolated from Chinese medicinal mushroom Coriolus versicolor, was able to enhance the cytotoxicity of certain S-phase targeted-drugs on human leukemic HL-60 cells via some cell-cycle and apoptotic-dependent pathways. The present study aimed to investigate whether the synergism of mechanisms of PSP with certain chemotherapeutic drugs also applies to human breast cancer. PSP treatment enhanced the cytotoxicity of doxorubicin (Doxo), etoposide (VP-16) but not cytarabine (Ara-C). Bivariate bromodeoxyuridine (BrdUrd)/DNA flow cytometry analysis estimated a longer DNA synthesis time (Ts) for the PSP treated cancerous cells suggesting that PSP enhanced the apoptotic effect of Doxo and VP-16 via creating an S-phase trap in the human breast cancer cell line ZR-75-30. The participation of PSP in the apoptotic machinery of the chemotherapeutic agents was further supported by a reduced ratio of protein expression of $\mathrm{Bcl}-\mathrm{x}_{\mathrm{L}} / \mathrm{Bax}$ of the cancer cells. This study provides further insight into the synergistic mechanisms of PSP and supports the hypothesis that the anti-cancer potentials of PSP is not limited to leukemia but may also be used as an adjuvant therapy for breast cancers.
\end{abstract}

\section{Introduction}

Breast cancer is one of the most frequent cancers in the world $(1)$, and it is the commonest cancer amongst women $(1,2)$. The mortality of breast cancer is low (1), however, because of its high incidence and the increasing global trend $(1,3,4)$, it results in medical costs worldwide estimated to be more than

Correspondence to: Dr Jennifer Man-Fan Wan, Food and Nutritional Science Division, School of Biological Sciences, Kadoorie Biological Sciences Building, The University of Hong Kong, Pokfulam Road, Hong Kong SAR, P.R. China

E-mail: jmfwan@hkusua.hku.hk

Key words: polysaccharopeptide, bromodeoxyuridine, doxorubicin, etoposide, cytarabine, human breast cancer, Chinese medicinal mushroom
US\$7 billion (3). The absence of estrogen receptor (ER) is found to be associated with higher recurrence rate (5), and patients with an ER-negative status have a significantly shorter median survival time (6). Hormonal therapy, one of the treatment used to tackle breast cancer, is reported to be completely ineffective in ER-negative breast cancers (7), therefore rendered the high importance of chemotherapy in ER-negative breast cancer patients.

However, chemotherapy comes with side effects such as alopecia (8) and leucopenia (9) because it does not differentiate between cancerous cells and normal cells (9-15). Many efforts have been put into the search for anti-tumor agents that can distinguish cancerous cells from normal cells, as well as adjuvant therapies that can enhance the cytotoxicity of the anti-tumor drugs to cancerous cells, which give potential of lowering chemotherapeutic drugs to reduce the side effects. Combined chemotherapy has also been tried in the hope of reducing the drug-induced side effects as well as increasing the anti-tumor specificity.

When searching for natural anticancer compounds for combination therapy, it is essential to identify novel compounds that are capable of potentiating the chemotherapeutic value of the anticancer drugs but at the same time exert no cytotoxic effect to normal cells. In this respect, the polysaccharopeptide (PSP), isolated from the mycelium of the medicinal Chinese mushroom of the species Coriolus versicolor, known as Yun Zhi, offers great potential in cancer combined treatment therapy because of its ability to distinguish cancerous cells from normal cells (16-20). PSP is currently in phase II clinical trials in China, with great success including high survival rates, improved immunological activities, appetite and comfort for patients status (19). The anticancer mechanisms of PSP include induction of apoptosis in cancer cells (21-24) and enhancement of host immune response (24-28).

The active component of Yunzhi, polysaccharopeptide (PSP), consists of 6 types of monosaccharides, namely mannose, glucose, xylose, galactose, arabinose and rhamnose, connected with a small polypeptide (17). Fig. 1 gives an illustration of the partial structure of the polysaccharide moiety of PSP. The polypeptide moieties of PSP are rich in aspartic and glutamic acids (Table I) (17-19). In a recent study, we have demonstrated that PSP was able to potentiate the chemotherapeutic activities of certain cell cycle-specific anticancer drugs. When combined with S-phase-specific 


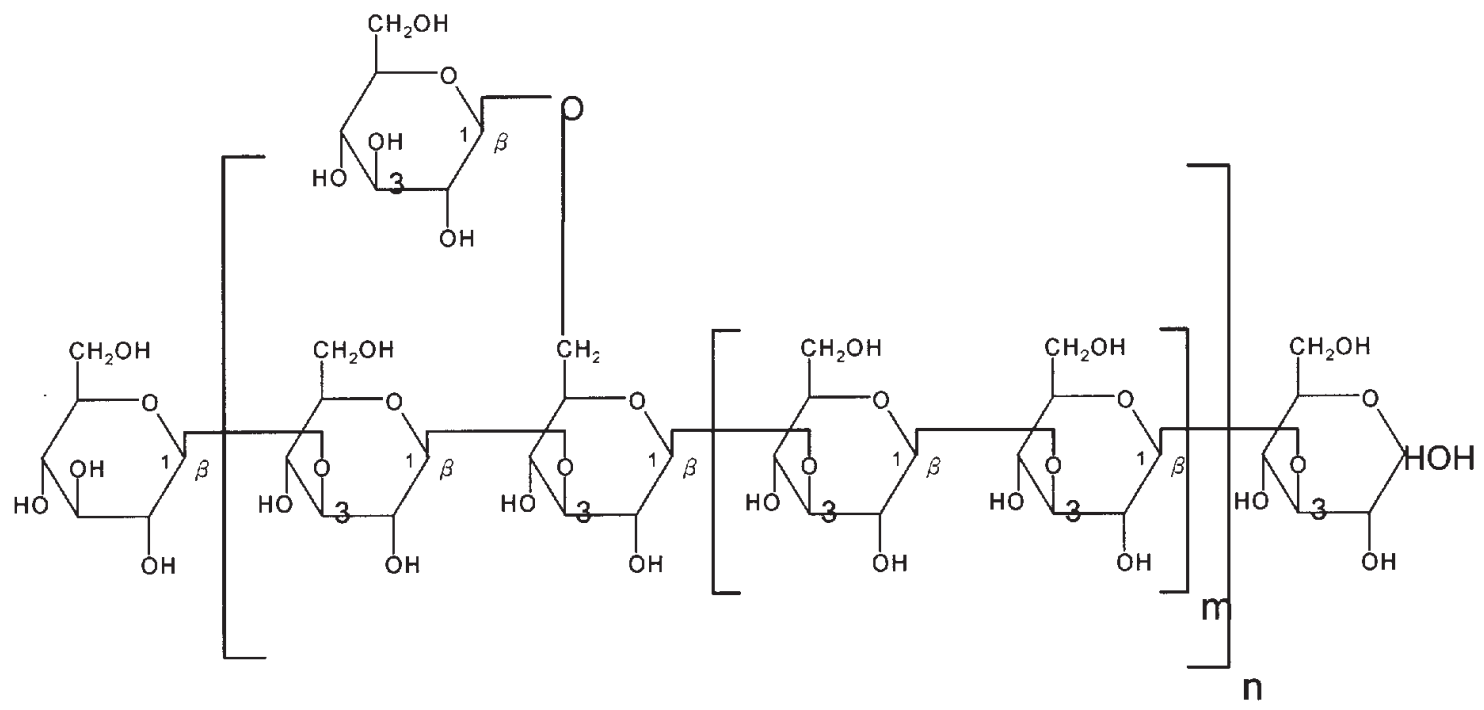

Figure 1. The partial structure of polysaccharide moiety of PSP (17).

Table I. Amino acids composition in polypeptide moiety of PSP (17).

\begin{tabular}{lclc}
\hline Amino acid & Content $(\%)$ & Amino acid & Content (\%) \\
\hline Aspartic acid & 4.0 & Methionine & 0.4 \\
Glutamic acid & 5.8 & Isoleucine & 2.2 \\
Threonine & 2.3 & Leucine & 2.4 \\
Serine & 3.2 & Tyrosine & 1.5 \\
Proline & 1.0 & Phenylalanine & 1.5 \\
Glycine & 2.6 & Tryptophan & 1.7 \\
Alanine & 2.6 & Lysine & 2.3 \\
Cystine & 0.9 & Histidine & 0.7 \\
Valine & 1.8 & Arginine & 1.8 \\
\hline
\end{tabular}

chemotherapeutic drugs, we observed that PSP was effective in potentiating the cytostatic and apoptotic effects of both doxorubicin (Doxo) and etoposide (VP) on the human leukemic HL-60 cells (24). In the present study, the ZR-75-30 cancer cell line, an estrogen receptor (ER) negative human breast cancer was chosen in order to investigate whether PSP can potentiate the cytostatic and apoptotic effects of doxorubicin, etoposide and cytarabine on human breast cancer.

The 5'-Bromo-2'-deoxyuridine (BrdUrd) labeling of DNA technique with flow cytometry (29-33) was applied to investigate the cell cycle-specific actions of PSP and its interaction with Doxo, VP-16, and Ara-C. The present study showed that the combined treatment of S-phase targeting drugs with PSP also resulted in higher cytotoxicity than drugs given alone in the ZR-75-30 cancer cells. Flow cytometry analysis indicates that PSP enhanced the cytotoxicity of the tested drugs by creating an S-phase trap in ZR-75-30 cells. This study provides further insight into the synergistic mechanisms of PSP and supports the hypothesis that the anti- cancer potentials of PSP is not limited to leukemia but may also be used as an adjuvant therapy for breast cancers.

\section{Materials and methods}

Reagents. Cytarabine (Ara-C), doxorubicin (Doxo), dimethyl sulfoxide (DMSO) and protease inhibitor cocktail were purchased from Sigma. Etoposide (VP-16) was purchased from Calbiochem. Polysaccharopeptide (PSP) was obtained from the Winsor Health Products Ltd. in form of capsules (340 mg/capsule). The crude powder of PSP was dissolved in distilled water, and the water soluble fraction was then freeze-dried. The freeze-dried powder was then dissolved in distilled water to prepare a solution at concentration of $10 \mathrm{mg} / \mathrm{ml}$. Stock solutions of Ara-C and Doxo were prepared in distilled water, and VP-16 was dissolved in DMSO. Annexin V binding assay easy to use detection kit (Apoptosis Detection Kit) was obtained from Trevigen Inc. Monoclonal anti-human Bcl-2, anti-human Bax, anti-human Bcl- $\mathrm{x}_{\mathrm{L}}$ and anti-human Bid antibody were supplied from Santa-Cruz Biotechnology.

Cell culture. ZR-75-30 cell line used in this study is an estrogen receptor (ER)-negative human breast cancer (34) derived from the ascite fluid of a 47-year-old post-menopausal Black women with infiltrating duct carcinoma (35) and it was a generous donation of Dr Mabel Young from the Department of Physiology, the University of Hong Kong. ZR-75-30 was routinely culture in RPMI medium supplemented with $10 \%$ fetal bovine serum. The densities of the cells were monitored to ensure they did not exceed $2 \times 10^{7}$ cells per $80 \mathrm{~cm}^{2}$ culture flask. Cells were cultured at $37^{\circ} \mathrm{C}$ in a humidified atmosphere with $5 \% \mathrm{CO}_{2}$. The cultures were supplied with fresh complete medium and the cell density was adjusted to $1 \times 10^{6}$ cells per flask every three days to maintain asynchronous and exponential growth. In all experiments, they were fed with fresh complete medium a day before the experiment.

Cell proliferation analysis. The time $(24,48,72 \mathrm{~h})$ and dosedependent $(0-400 \mu \mathrm{g} / \mathrm{ml})$ effect of PSP on the proliferation of 
ZR-75-30 human breast cancer cells were studied by culturing the cells with or without (RPMI only) PSP as described above. Preparation of PSP has been described elsewhere by us $(16,24)$. After trypsinization, $100 \mu \mathrm{l}$ cancer cell aliquots and $100 \mu 1$ of Trypan-blue solution was added to a $1.5 \mathrm{ml}$ microcentrifuge tube which was then mixed thoroughly and incubated at room temperature for $5 \mathrm{~min}$. Total number of cells in four $1 \mathrm{~mm}^{2}$ corners of hemacytometer was counted, and the average number of cells per unit volume of medium was calculated.

Study 1: the influence of cell cycle kinetics of PSP on ZR-75-30 human breast cancer cells measured by bivariate BrdUrd/ DNA flow cytometry. Previous report with human leukemic cells $(16,24)$ indicated that one of the anticancer properties of PSP involves S-phase cell cycle arrest. This study sought to investigate the influence of cell cycle kinetics of PSP on the ZR-75-30 human breast cancer cells by using the bromodeoxyuridine labeling and bivariate BrdUrd/DNA technique analysis by flow cytometry.

To investigate the effect of PSP on tumor growth and cell cycle distribution $\left(\mathrm{G}_{0} / \mathrm{G}_{1}, \mathrm{~S}\right.$ and $\left.\mathrm{G}_{2} / \mathrm{M}\right)$, ZR-75-30 cell suspensions at $2 \times 10^{6}$ cells were exposed with or without PSP at concentrations ranging between 5 and $400 \mu \mathrm{g} / \mathrm{ml}$. The cells were incubated for 24,48 or $72 \mathrm{~h}$, harvested and examined by various analyses. The fixed samples were stored at $-20^{\circ} \mathrm{C}$ for further analysis by DNA/PI flow cytometry.

To study the effect of PSP on the cell cycle kinetics [labeling index (LI), relative movement (RM), DNA synthesis time (Ts) and $\mathrm{G}_{0} / \mathrm{G}_{1}$ cells returned or labeled divided cells (Lud)], ZR-75-30 cells with 48-h pretreatment of PSP (50 $\mu \mathrm{g}$ / $\mathrm{ml}$ ) or without (control) were pulsed with $10 \mu \mathrm{M}$ of BrdUrd for $20 \mathrm{~min}$. After pulse-labeling with BrdUrd, cells were washed with warm cell culture medium, divided and subjected to culture incubation for 1 or $6 \mathrm{~h}$. At the end of incubation, cells were harvested and fixed with ice-cold $75 \%$ ethanol. The fixed samples were stored at $-20^{\circ} \mathrm{C}$ for further analysis by flow cytometry.

The bivariate BrdUrd/DNA technique analysis by flow cytometry is based on simultaneous measurement of the total incorporation or the rate of incorporation of the thymidine analog, BrdUrd, into newly synthesized DNA (30-32). The uptake of BrdUrd in each cell can be detected by immunocytochemical staining techniques that involve binding the BrdUrd to fluorescein isothiocyanate (FITC) labeled antiBrdUrd monoclonal antibodies (green fluorescence). The quantity of BrdUrd (green fluorescence) and DNA (red fluorescence labels by propidium iodide) can be simultaneously measured in the same cells. This analysis estimates the relative number of cells actually involved in cell division (labeling index) and may also provide estimates of the rate of DNA synthesis.

By repeating the bivariate BrdUrd/DNA analysis of labeled cells at several time-points, it is possible to determine the rate of progression of BrdUrd-labeled cells as they accumulate more DNA. The movement of the BrdUrd-labeled cells (cycling cells) between the $G_{0} / G_{1}$ and $G_{2} / M$ cell cycle phases can be used to calculate the 'relative movement' (RM). By using two different relative movements $(\mathrm{RM}(\mathrm{t}))$ extracted from the different BrdUrd pulse-labeling time, the DNA synthesis time (Ts) of the cancer cells can be calculated according to the methods previously described (29-33):

$$
\begin{aligned}
& \mathrm{RM}(\mathrm{t})=\left(\mathrm{F}_{\mathrm{lud}(\mathrm{t})}-\mathrm{F}_{\mathrm{G} 0 / \mathrm{G} 1}\right) /\left(\mathrm{F}_{\mathrm{G} 2 / \mathrm{M}}-\mathrm{FG}_{0} / \mathrm{G}_{1}\right) \\
& \mathrm{Ts}=0.55(\mathrm{t}) /(\mathrm{RM}(\mathrm{t})-\mathrm{RM}(0))
\end{aligned}
$$

where Flud(t), $\mathrm{FG}_{0} / \mathrm{G}_{1}$ and $\mathrm{FG}_{2} / \mathrm{M}$ are the mean PI fluorescence (DNA content) of the BrdUrd labelled undivided cells of the $\mathrm{G}_{0} / \mathrm{G}_{1}$ and $\mathrm{G}_{2} / \mathrm{M}$ population at time (t) (hour) after BrdUrd pulsing. $\mathrm{RM}(0)$ and $\mathrm{RM}(\mathrm{t})$ are the relative movement values at time 0 and $\mathrm{t}$ (hour) after BrdUrd pulsing respectively. $\mathrm{RM}(0)$ is estimated to be 0.55 .

Immunocytochemical staining for BrdUrd/DNA flow cytometry analysis. Staining of cancer cells for bivariate analysis of BrdUrd was performed as previouly described by us $(29,33,36)$ and by other investigators (30) with some modifications. Cells were harvested into $15 \mathrm{ml}$ centrifuge tubes. All samples were washed twice with $10 \mathrm{ml}$ PBS and centrifuged at $400 \mathrm{~g}$ for $5 \mathrm{~min}$. Supernatant was removed and cell pellets were re-suspended in $100 \mu 1$ ice-cooled PBS. Cells were fixed by adding ice-cold EtOH (70\% w/v in Milli-Q water) dropwisely into the tubes while the cells were being vortexed. The fixed samples were stored at $-20^{\circ} \mathrm{C}$ for further analysis.

The fixed samples were washed twice each with $10 \mathrm{ml}$ PBS and the DNA of cells were partially denatured by incubation with $2 \mathrm{M} \mathrm{HCl}(0.5 \mathrm{ml})$ for $30 \mathrm{~min}$. After denaturation, cells were washed three times with $10 \mathrm{ml}$ PBS containing $0.05 \%$ Tween-20 (PBS-T). The cells were incubated with $100 \mu \mathrm{l}$ of anti-BrdUrd antibody (1:100 dilution) and incubated at room temperature for $1 \mathrm{~h}$. After incubation, cells were washed twice with PBS-T and subsequently incubated with $100 \mu \mathrm{l}$ of FITC-conjugated anti-mouse IgG antibody (1:40 dilution) to label the primary antibodies in dark at room temperature for $1 \mathrm{~h}$. Following the incubation, cells were washed twice with PBS and the DNA of cells was stained with propidium iodide (PI) staining solution $(50 \mu \mathrm{g} / \mathrm{ml} \mathrm{PI}, 10 \mu \mathrm{g} / \mathrm{ml}$ RNase, $0.01 \mathrm{M}$ Tris-base and $10 \mathrm{mM} \mathrm{NaCl}$ in milli-Q water) for $30 \mathrm{~min}$ at room temperature. The stained cells were analyzed by Coulter's Epics Elite ESP flow cytometer at $525 \mathrm{~nm}$ and $620 \mathrm{~nm}$ band pass filters.

Study 2: The combined anticancer effect of PSP with doxorubicin (Doxo), etoposide (VP-16) and cytarabine (Ara-C). Based on the cell cycle kinetic study of study 1 , the testing hypothesis of this study was that by creating an S-phase trap, PSP can enhance the cell killing effect of chemotherapeutic agents namely doxorubicin, etoposide and cytarabine with S-phase interference activity on the ZR-75-30 cells. The ZR-75-30 cells were treated with PSP $(50 \mu \mathrm{g} / \mathrm{ml})$ or without (non PSP treated) for $48 \mathrm{~h}$ before adding the individual tested drugs. Both PSP pretreated and non-PSP treated cells were exposed to $5 \mu \mathrm{M}$ of Ara-C, VP-16 or Doxo for further $18 \mathrm{~h}$. The total treatment time of PSP was $66 \mathrm{~h}$. Cells were harvested for annexin V/PI flow cytometry analysis for cell death and Western blot analysis of the Bcl-2 family genes.

Quantification of cell death by annexin V/PI flow cytometry. The theoretical background of this detection method has been previously described (37). Annexin V binding assay was 
(a)

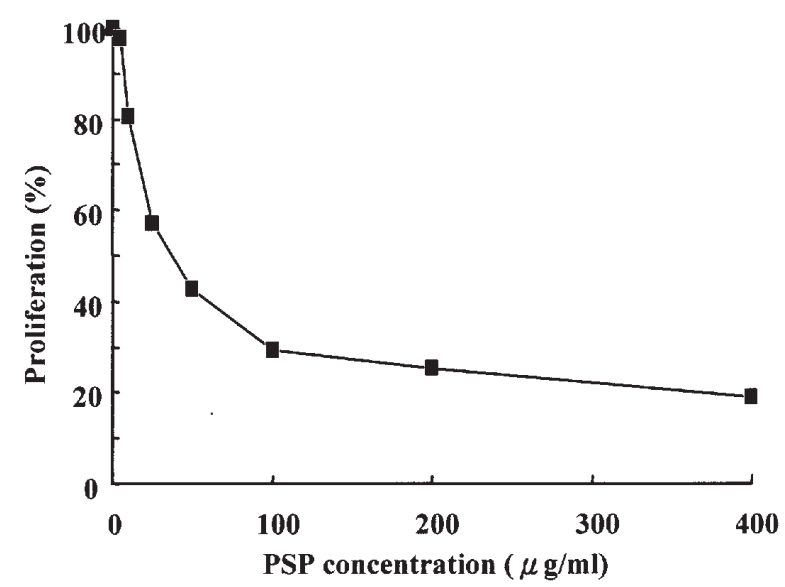

(b)

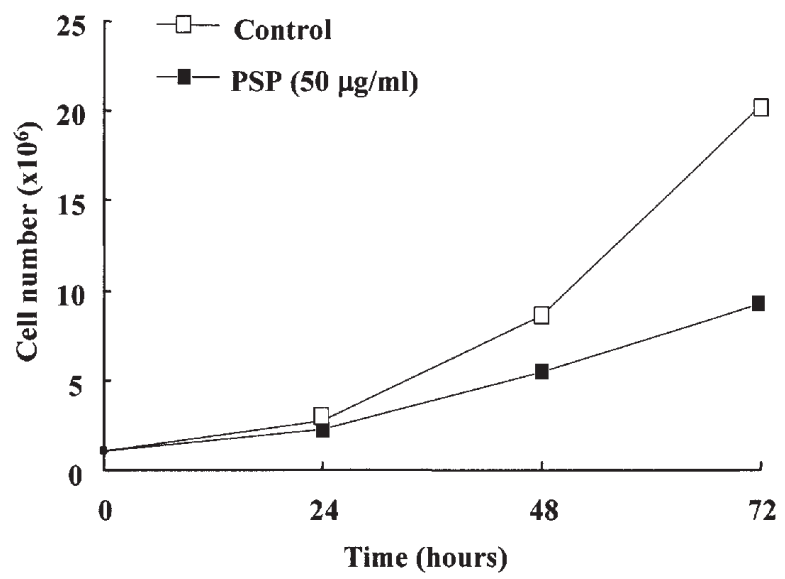

Figure 2. The time and dose effect of PSP on the proliferation of human breast cancer ZR-75-30 cell proliferation. (a) dose-dependent effect; (b) time-dependent effect.

performed by using an apoptosis detection kit. Cells $\left(2 \times 10^{5}\right)$ after incubation with or without PSP and drugs were harvested and centrifuged at $400 \mathrm{x}$ g for $5 \mathrm{~min}$ to remove culture medium. Cell pellets were washed with $3 \mathrm{ml}$ phosphate buffer saline (PBS) and re-suspended in $500 \mu \mathrm{l}$ binding buffer. After centrifugation and removal of binding buffer, $100 \mu 1$ of annexin $\mathrm{V}$ incubation reagent $(10 \mu 110 \mathrm{X}$ binding buffer, $10 \mu 1$ propidium iodide (PI), $1 \mu 1$ annexin $\mathrm{V}$ conjugate and $79 \mu 1$ milli-Q water) was added to each sample. The samples were incubated for $15 \mathrm{~min}$ in the dark at room temperature. The cell suspension was then diluted with $400 \mu$ l binding buffer and was analyzed by flow cytometer.

Western blot analysis of the expression of Bcl-2 family proteins. Cells were harvested and washed twice with ice-cold PBS $(45 \mathrm{ml})$ followed by centrifugation at $400 \mathrm{x} \mathrm{g}$ for $5 \mathrm{~min}$. Cell pellet was re-suspended in lysis buffer $\left(5 \times 10^{6}\right.$ cells $/ 100 \mu 1$ lysis buffer) with HEPES (25 mM; pH 7.5), $\mathrm{NaCl}(150 \mathrm{mM})$, $\operatorname{EDTANa}_{2}(1 \mathrm{mM})$, DTT $(1 \mathrm{mM})$, Triton X-100 (1\%) and protease inhibitor cocktail. The suspension was then frozen and thawed three times by cold methanol at $-80^{\circ} \mathrm{C}$. The iced suspension was sonicated to melting point. Cell suspension was then placed in ice for further $30 \mathrm{~min}$ and then centrifuged. After centrifugation at $14,000 \mathrm{x}$ g for $30 \mathrm{~min}$ at $4^{\circ} \mathrm{C}$, the suspension was collected and stored at $-80^{\circ} \mathrm{C}$. Protein quantity was determined by Bradford assay. Protein extracts were mixed with equal volume of $2 \mathrm{X}$ sample buffer $(0.125 \mathrm{M}$ Tris-HCl, 4\% SDS, 20\% v/v glycerol, $0.2 \mathrm{M}$ DTT, $0.02 \%$ bromophenol blue, $\mathrm{pH}$ 6.8) and the mixture was boiled in water for $3 \mathrm{~min}$.

Equal amounts of total protein $(20 \mu \mathrm{g})$ were subjected to 12.5\% SDS-PAGE followed by Western blotting onto a PVDF membrane. Membranes were incubated with anti-human Bcl-2, anti-human Bax, anti-human Bid and anti-human $\mathrm{Bcl}-\mathrm{x}_{\mathrm{L}}$ antibodies, and detected with the matching species-specific secondary HRP-conjugated antibodies. Proteins were detected using the ECL system (GE Healthcare) and the band intensity was measured by Quantity One software (Bio-Rad).
Statistical analysis. All data are presented as mean \pm standard error of the mean (SEM). Statistical significance was calculated using two-tail Student's t-test for two groups and One-way ANOVA analysis for multi-group comparison. $\mathrm{p}<0.05$ was considered as statistically significant.

\section{Results}

The anti-proliferation effect of PSP on ZR-75-30 cells. Treatment with PSP delayed the proliferation of ZR-75-30 cells in a dose-dependent (Fig. 2a) and time-dependent (Fig. 2b) manner. At $50 \mu \mathrm{g} / \mathrm{ml}$ of PSP, proliferation was decreased by $36.8 \%$ after 48 -h treatment. Measured by annexin V/PI flow cytometry, at 72-h treatment, PSP induced significant cell death $(\mathrm{p}<0.001)$ by $23.9 \%$ (Fig. 3 ).

Effect of PSP on the human breast cancer ZR-75-30 cell cycle distribution. The cell cycle distribution of ZR-75-30 cells, measured by DNA/PI flow cytometry, shows that PSP was capable of inhibiting the cell proliferation via alteration of cell cycle. At $48 \mathrm{~h}$, PSP induced cell arrest in the S-phase by $34 \%(p<0.01)$ with a corresponding decrease of cell proportions in $G_{0} / G_{1}$ and $G_{2} / M$ phases (Fig. 4) compared to control.

Effect of PSP on labeling index (LI), relative movement $(R M)$, and DNA synthesis time (Ts) of human breast cancer ZR-75-30 cells. Fig. 5 presents the contour plot of the bivariate BrdUrd/DNA flow cytometry analysis from the 1and 6-h BrdUrd pulse labeling of the PSP treated and control (non-PSP treated) cells. The S-phase BrdUrd labeled cell population of the 1-h BrdUrd contour plot is used to estimate the labeling index (LI) of the cancer cells as described (2933). The 6-h contour plots show that the BrdUrd labeled cells have moved through the S-phase in the cell cycle and some had not yet divided (Lud) whereas others had done so. The newly divided daughter cells population detected by antiBrdUrd-monoclonal antibodies of the $G_{0} / G_{1}$ phase was used to 

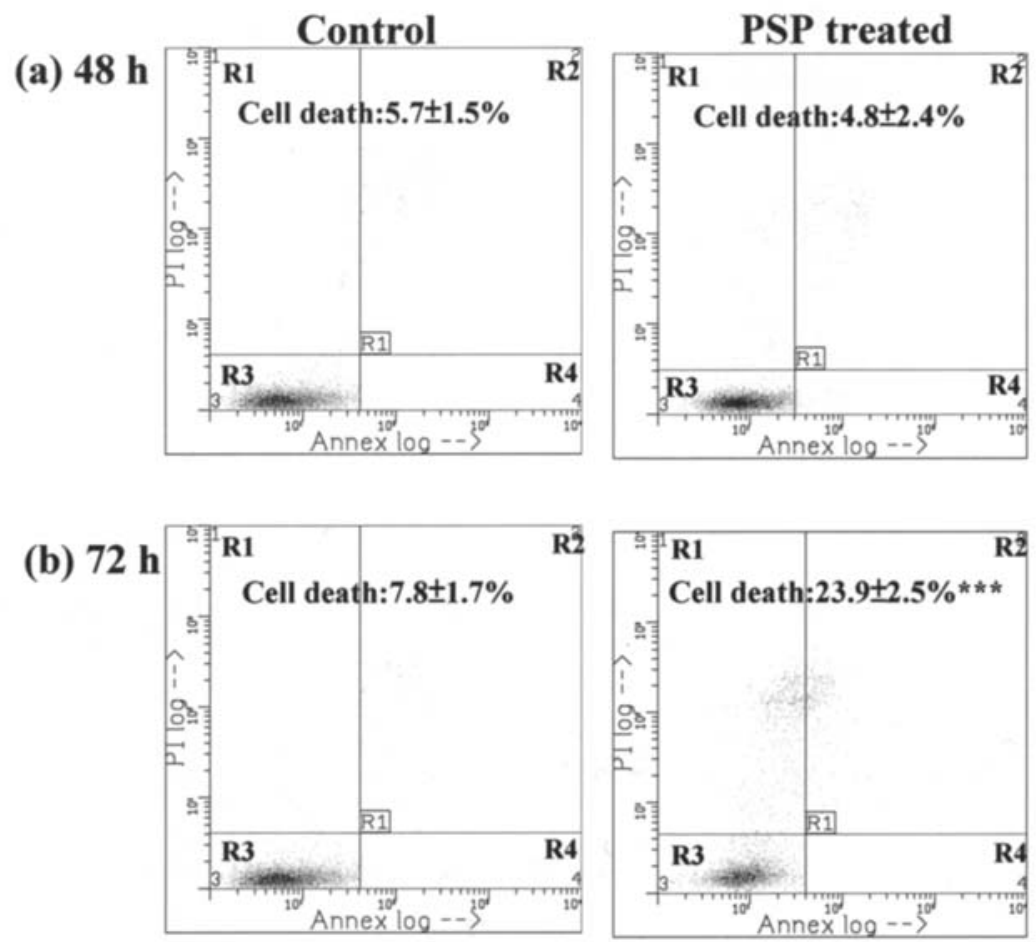

Figure 3. The effect of PSP on cell death of ZR-75-30 cells. The cells without (control) and with PSP (50 $\mu \mathrm{g} / \mathrm{ml})$ treatment for 48 and $72 \mathrm{~h}$ were subjected to annexin V/PI flow cytometry analysis. The dot plots representing data on viable cells (R3) and dead cells (R1, R2, R4) at 48 and $72 \mathrm{~h}$, respectively. Values are mean \pm SEM $(n=4) .{ }^{* * *} \mathrm{p}<0.001$ compared with control.

\section{Control}

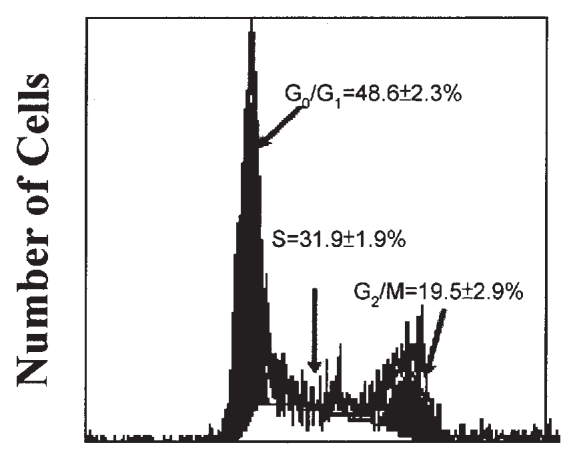

PSP treated

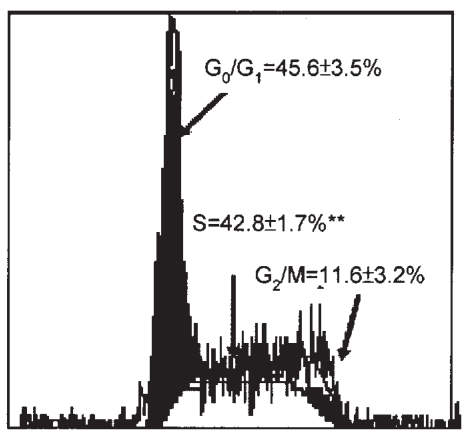

Figure 4. The effect of PSP on the cell cycle distribution. Cancer cells without (control) or with $50 \mu \mathrm{g} / \mathrm{ml}$ PSP incubation for $48 \mathrm{~h}$ were fixed with PI for staining of DNA. The cell population (\%) distribution among the $\mathrm{G}_{0} / \mathrm{G}_{1}, \mathrm{~S}$ and $\mathrm{G}_{2} / \mathrm{M}$ phase was analyzed by DNA/PI flow cytometry. Values are mean \pm SEM $(\mathrm{n}=4) .{ }^{* *} \mathrm{p}<0.01$ compared with control.

calculate the labeled divided cells $(\mathrm{Ld})$. The relative movement calculated from the 6-h BrdUrd/DNA flow cytometry (RM 6) (Fig. 5) was used to calculate the DNA synthesis time (Ts) of the cancer cells. Table II summarized the effect of PSP on LI, RM, Ld and Ts of the cancer cells with and without PSP treatment. The data show that PSP arrested cells in S-phase and resulted in significant higher calculated labeling index. It is noteworthy that PSP treatment significantly $(\mathrm{p}<0.01)$ retarded the relative movement ( 1 and $6 \mathrm{~h}$ ) of the cancer cells. PSP arrested cells in S-phase resulted in a hyper-prolongation from 12.51 to $18.31 \mathrm{~h}$ for the DNA synthesis of the cancer cells. The DNA synthesis time of ZR-75-30 cells was extended by $46.4 \%$ $(\mathrm{p}<0.01)$. Calculation of the labeled divided cells also dropped from 8.58 to $3.67 \%$ suggesting some interference might have occurred at the $\mathrm{G}_{2} / \mathrm{M}$ phase.

The effect of anti-tumor drugs alone and PSP pretreatment with anti-tumor drug on cell death and cell viability in ZR-75-30. To investigate the interaction of PSP with the chemotherapeutic drugs, cell death was performed with annexin V/PI flow cytometry. Fig. 6 indicates that comparing to the cancer cells administered only the corresponding individual chemotherapeutic agent treatment, the apoptotic effect of Ara-C, 
(a) $1 \mathrm{~h}$

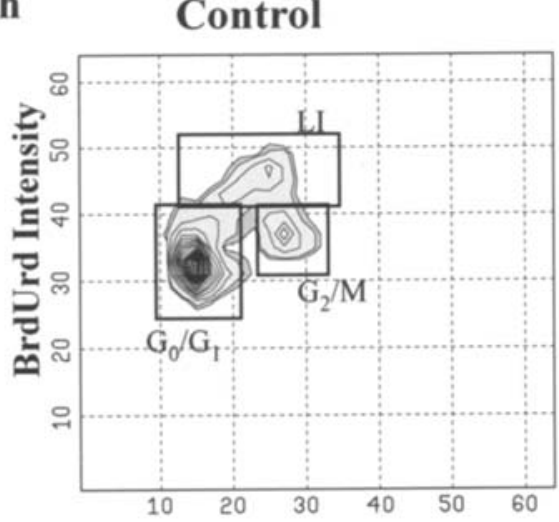

(b) $6 \mathrm{~h}$

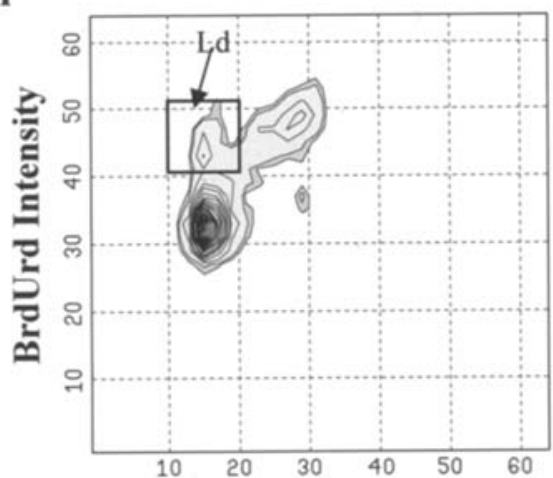

PSP treated
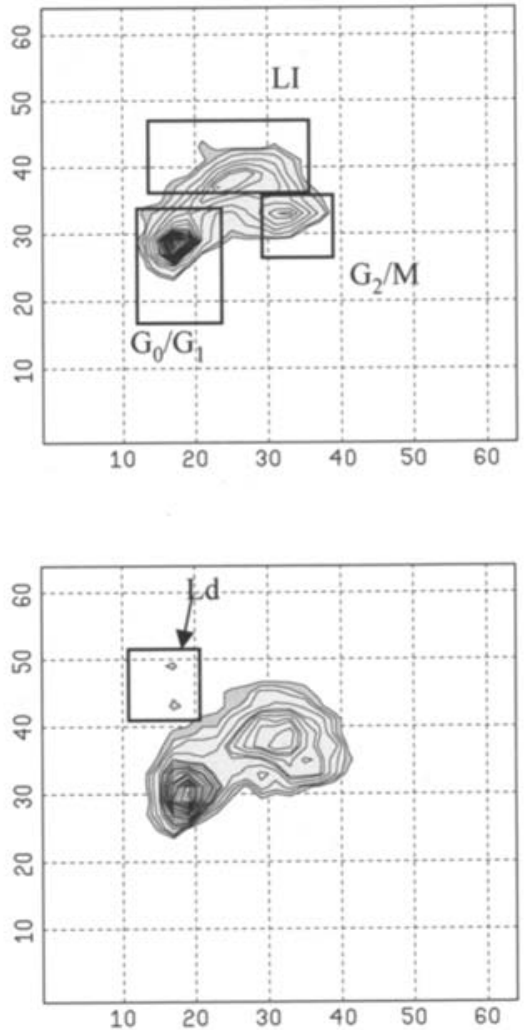

Figure 5. The effect of PSP on the labeling index and labeled divided cells: measured by bivariate BrdUrd/DNA flow cytometry. Contour plots of bivariate BrdUrd/DNA flow cytometry distribution of the breast cancer cells without or with PSP $(50 \mu \mathrm{g} / \mathrm{ml})$ treatment for $48 \mathrm{~h}$ were generated from the $1 \mathrm{and} 6 \mathrm{~h}$ BrdUrd pulse labels, respectively. The S-phase cells situated in between $2 \mathrm{~N}\left(\mathrm{G}_{0} / \mathrm{G}_{1}\right)$ and $4 \mathrm{~N}\left(\mathrm{G}_{2} / \mathrm{M}\right)$ labeled positively with BrdUrd, and this population of cells were used to estimate the labeling index (LI, \%). The 6-h BrdUrd/DNA contour plot shows that some S-phase cells incorporated BrdUrd and had progressed through the $\mathrm{G}_{2} / \mathrm{M}$ phase; further divided and appeared in $\mathrm{G}_{0} / \mathrm{G}_{1}$ as daughter cells or labeled divided cells (Ld). Some cells remained undivided and expressed as labeled undivided cells (Lud). Values are mean $\pm \operatorname{SEM}(n=4) .{ }^{* *} \mathrm{p}<0.01$ compared with control.

Table II. The effect of PSP on labeling index, labeled divided cells, relative movement and DNA synthesis time of the ZR-75-30 cells.

\begin{tabular}{|c|c|c|c|c|c|}
\hline & Time (h) & LI (\%) & $\operatorname{Ld}(\%)$ & $\mathrm{RM}$ & Ts \\
\hline Control & 1 & $31.9 \pm 0.4$ & & $0.66 \pm 0.01$ & \\
\hline PSP & 1 & $42.8 \pm 1.3^{\mathrm{a}}$ & & $0.59 \pm 0.01^{\mathrm{a}}$ & \\
\hline Control & 6 & & $8.58 \pm 0.52$ & $0.82 \pm 0.01$ & $12.51 \pm 0.56$ \\
\hline PSP & 6 & & $3.67 \pm 0.24^{\mathrm{a}}$ & $0.73 \pm 0.01^{\mathrm{a}}$ & $18.31 \pm 0.63^{\mathrm{a}}$ \\
\hline \multicolumn{6}{|c|}{$\begin{array}{l}\text { All data are expressed as mean } \pm \text { SEM }(\mathrm{n}=4) .{ }^{\mathrm{a}} \mathrm{p}<0.01 \text { vs control; PSP }(50 \mu \mathrm{g} / \mathrm{ml}) \text {. LI, labeling index, extracted from the } 1 \text {-h bivariate } \\
\text { BrdUrd/DNA flow cytometric contour plot; } \mathrm{Ld} \text {, labeled divided, extracted from the } 6 \text {-h bivariate BrdUrd/DNA flow cytometric contour plot; } \\
\mathrm{RM} \text {, relative movement; extracted from both } 1-\text { and } 6 \text {-h bivariate BrdUrd/DNA flow cytometric contour plot; Ts, DNA synthesis time; } \\
\mathrm{Ts}=0.55(\mathrm{t}) /(\mathrm{RM}(\mathrm{t})-\mathrm{RM}(0)) \text {, where Flud }(\mathrm{t}), \mathrm{FG}_{0} / \mathrm{G}_{1} \text { and } \mathrm{FG}_{2} / \mathrm{M} \text { are the mean PI fluorescence }(\mathrm{DNA} \text { content) of the BrdUrd labelled undivided } \\
\text { cells of the } \mathrm{G}_{0} / \mathrm{G}_{1} \text { and } \mathrm{G}_{2} / \mathrm{M} \text { population at time }(\mathrm{t}) \text { (hour) after BrdUrd pulsing; } \mathrm{RM}(0) \text { and } \mathrm{RM}(\mathrm{t}) \text { are the relative movement values at time } 0 \text { and } \\
\mathrm{t} \text { (hour) after BrdUrd pulsing, respectively. } \mathrm{RM}(0) \text { is estimated to be } 0.55 \text {. }\end{array}$} \\
\hline
\end{tabular}

Doxo and VP-16 on the ZR-75-30 cells was further enhanced in cells with PSP pretreatment by $18.8 \%, 55.4 \%(\mathrm{p}<0.001)$ and $161 \%(\mathrm{p}<0.001)$, respectively. The viability of these cells dropped by $8.8,33.2(\mathrm{p}<0.001)$ and $48.8 \%(\mathrm{p}<0.001)$ with Ara-C, Doxo, and VP-16, respectively.
Effect of PSP with and without Ara-C, Doxo and VP-16 on apoptotic protein expression in human breast cancer $Z R-75-30$ cells. Western blot analysis of protein level presented in Fig. 7 shows that among the apoptotic genes measured, Bax gene expression was the strongest in the ZR-75-30 cells. Fig. 8 

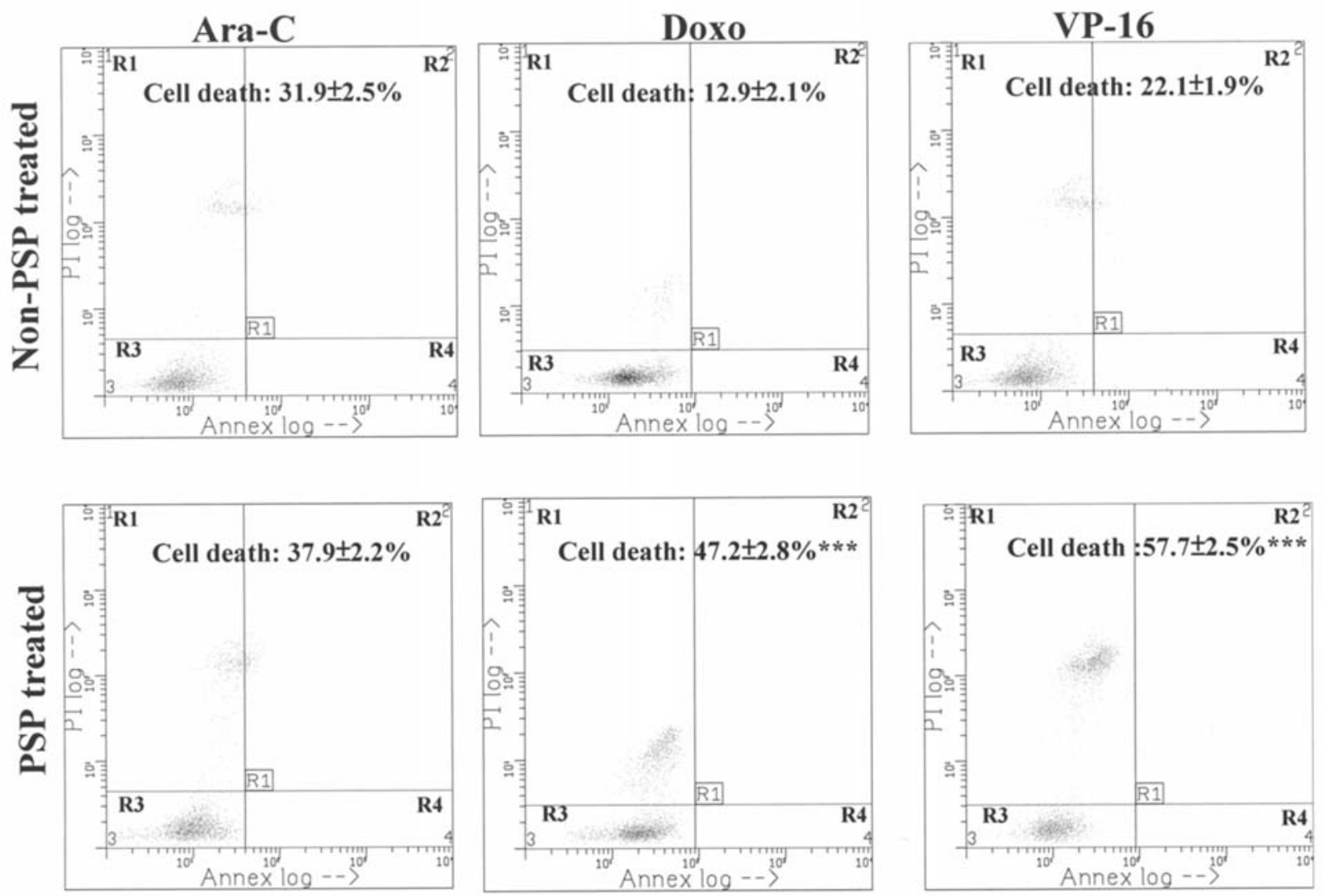

Figure 6. The combined effect of PSP with Ara-C, Doxo or VP-16 on the cell death of ZR-75-30 cells. The cancer cells either without (non-PSP) or with PSP $(50 \mu \mathrm{g} / \mathrm{ml})$ pretreatment for $48 \mathrm{~h}$ all received $5 \mu \mathrm{M}$ of Ara-C, Doxo or VP-16 for $18 \mathrm{~h}$. The total treatment time of PSP was $66 \mathrm{~h}$. The population of dead cells was determined by Annexin V/PI flow cytometry. The R3 represents viable cells and the R1, R4 and R2 areas represent dead cells (PI+ ${ }^{+}$Annexin ${ }^{+}$or both). Values are mean $\pm \operatorname{SEM}(\mathrm{n}=4) .{ }^{* * *} \mathrm{p}<0.001$ compared with non-PSP treated.

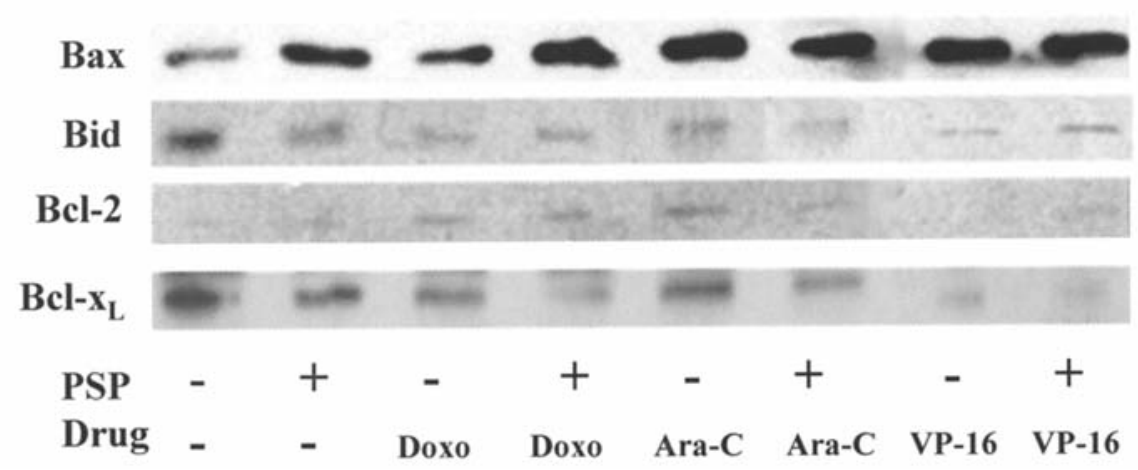

Figure 7. The combined effect of PSP with Ara-C, Doxo, VP-16 on expression of the cell death proteins Bcl- $\mathrm{x}_{\mathrm{L}}$ Bid and Bax. The cancer cells either with or without PSP pretreatment for $48 \mathrm{~h}$ all received $5 \mu \mathrm{M}$ of Ara-C, Doxo or VP-16 for $18 \mathrm{~h}$. The total treatment time of PSP was $66 \mathrm{~h}$.

summarizes the relative expression of the Western plotted proteins and shows that comparing to the control, PSP treatment alone increased the pro-apoptotic Bax expression by $107 \%$ while that of Bid was reduced by $45 \%$. Expression of the anti-apoptotic protein $\mathrm{Bcl}-\mathrm{x}_{\mathrm{L}}$ was reduced by $51 \%$. When comparing the chemotherapeutic agents, they produced similar effects, i.e. increasing Bax expression and decreasing Bcl- $\mathrm{x}_{\mathrm{L}}$ and Bid expression. Doxo treatment increased Bax expression by $39 \%$ and reduced $\mathrm{Bcl}-\mathrm{x}_{\mathrm{L}}$ and Bid expression by 39 and $62 \%$, respectively. Ara-C treatment increased expression of Bax by $209 \%$ and decreased $\mathrm{Bcl}-\mathrm{x}_{\mathrm{L}}$ by $45 \%$. Expression of Bid was decreased by $70 \%$ as well. VP-16 treatment increased Bax expression by $220 \%$, while Bcl- $\mathrm{x}_{\mathrm{L}}$ and Bid expression were decreased by 52 and $90 \%$, respectively.

Compared with the corresponding non-PSP treated groups, combination treatment of PSP with Doxo increased the expression of Bax by $92.1 \%$ and slightly decreased the expression of $\mathrm{Bcl}-\mathrm{x}_{\mathrm{L}}$ by $24.6 \%$. The change of bid expression in Doxo with PSP is insignificant. In the combination treatment of 
(a)

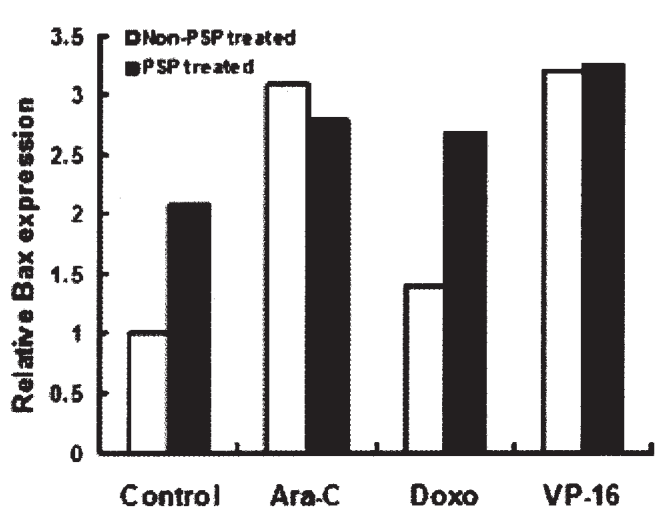

(c)

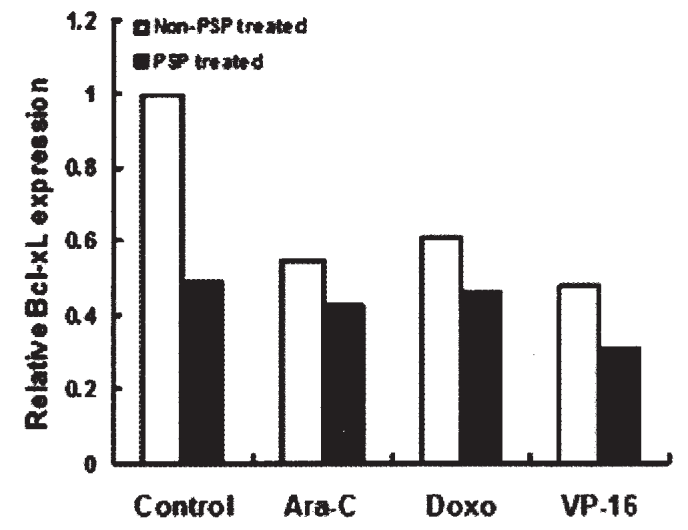

(b)

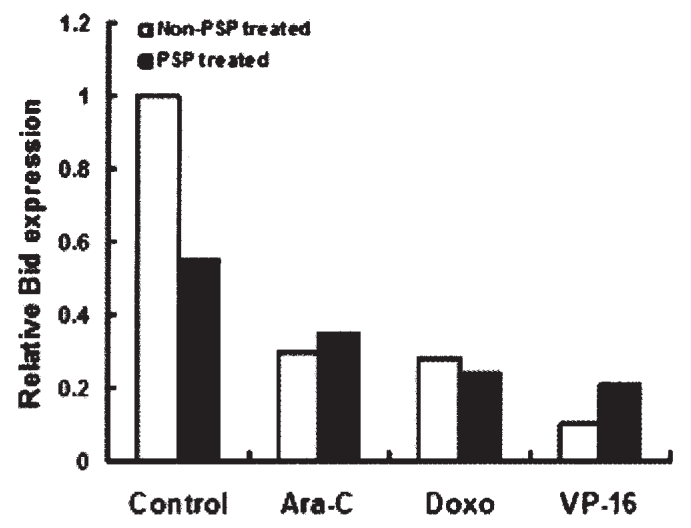

(d)

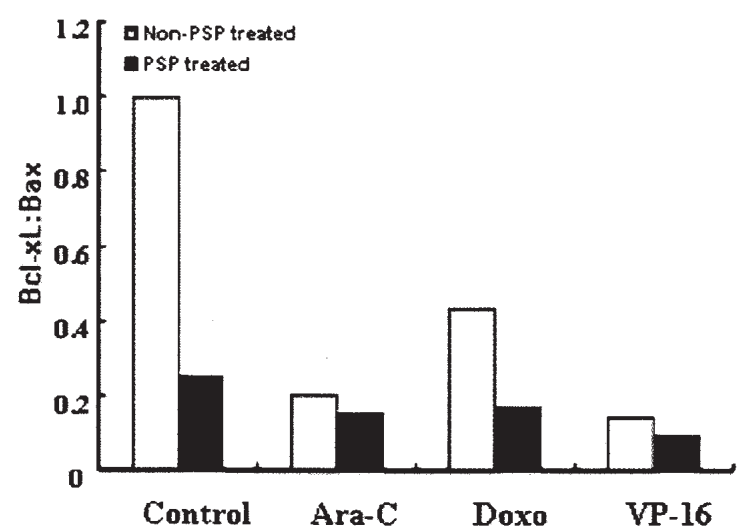

Figure 8. The combined effect of PSP with Ara-C, Doxo or VP-16 on the relative expression of the cell death proteins Bcl- $\mathrm{x}_{\mathrm{L}} \mathrm{Bid}$, Bax and Bcl- $\mathrm{x}_{\mathrm{L}} / \mathrm{Bax}$ ratio. The cancer cells either with or without PSP pretreatment for $48 \mathrm{~h}$ all received $5 \mu \mathrm{M}$ of Ara-C, Doxo or VP-16 for $18 \mathrm{~h}$. The total treatment time of PSP was $66 \mathrm{~h}$. The relative expression of (a) Bax; (b) Bid; (c) Bcl- $\mathrm{x}_{\mathrm{L}}$ and (d) $\mathrm{Bcl}-\mathrm{x}_{\mathrm{L}} / \mathrm{Bax}$ ratio.

PSP with VP-16, the change in Bax expression is insignificant while Bid expression was doubled. Bcl- $\mathrm{x}_{\mathrm{L}}$ expression was decreased by $35.4 \%$. Combined treatment of PSP with Ara-C, to our surprise, reduced the expression of Bax by $9.4 \%$, while $\mathrm{Bcl}-\mathrm{x}_{\mathrm{L}}$ expression was decreased by $21.8 \%$. Change in Bid expression is insignificant.

Fig. 8d shows that all treatment groups decreased the Bcl- $\mathrm{x}_{\mathrm{L}} / \mathrm{Bax}$ ratio. PSP alone decreased the ratio by $76.45 \%$ while Ara-C, Doxo and VP-16 given alone decreased the ratio by $82.4,56.0$ and $84.9 \%$, respectively. Compared with the corresponding non-PSP treated groups, PSP further decreased the $\mathrm{Bcl}-\mathrm{x}_{\mathrm{L}} / \mathrm{Bax}$ ratio induced by Doxo by $60.6 \%$, Ara-C by $13.0 \%$ and VP-16 by $37.5 \%$.

\section{Discussion}

Breast cancer is one of the most frequent cancers in the world $(1)$, and it is the commonest cancer amongst women $(1,2)$. Because of the advancement in breast cancer therapy, the mortality is low compared to other types of cancers (1). Therapies used for breast cancer include hormonal therapy $(7,38)$, chemotherapy $(39)$, a combination of both $(40)$, and surgical removal of the malignant tissue. Surgical removal results in psychological issues such as low self-esteem (41), which is highly undesirable. Hormonal therapy is reported to be ineffective in ER-negative breast cancers (7), therefore chemotherapy in ER-negative breast cancers is very important. Many chemotherapeutic agents, however, are also toxic to normal cells (10-15), leading to side effects like loss of hair (8), impaired immune function (9), etc. which limited their efficacy.

Combined chemotherapy offers hope and the success depends on the interaction between the candidate drugs (42-44). Several drugs with similar cell cycle-dependent properties can be scheduled properly to produce a maximal killing effect in combined chemotherapy. In this regard, PSP is likely a potential candidate as an adjuvant therapy for cancer treatment via its cell cycle interaction with the cytotoxic action of several S-phase targeting chemotherapeutic agents. The superior property of PSP over other chemotherapeutic drugs can be its ability to distinguish cancerous cells from normal cells $(16,18-20)$.

Generally speaking, a phase-specific anticancer agent will produce a maximal cell killing effect only if it allows cycling cells to enter the cytotoxic phase, i.e. the S-phase (42-46). In the present study, we have demonstrated that by encouraging the cycling cells to enter the cytotoxic S-phase, PSP potentiated the cell killing effect of the two S-phase targeting drugs 
Doxo and VP-16 (10,47-52) but not Ara-C on the human breast cancer ZR-75-30 cells (Fig. 6). The flow cytometric method used in the current study is based on simultaneous measurements of BrdUrd incorporation into cellular DNA (S-phase) and total cellular DNA content. This technique potentially overcomes many of the problems associated with the use of radioactive labels and autoradioactivity required to measure cell kinetics. By use of a single 'pulse' labeling of BrdUrd and harvesting and staining of the cancer cells for BrdUrd and DNA at two time points, it was possible to obtain detailed estimates of DNA synthesis time Ts. The extended Ts (from 12 to $18 \mathrm{~h}$ ) of the PSP-pretreated ZR-75-30 cells indicated that DNA synthesis of the cycling cells in the cytotoxic phase had been affected to a certain extent. With the interference of DNA synthesis process, PSP provoked the cell death of the ZR-75-30 cells induced by cell cycle specific cytotoxic anticancer agents Doxo and VP-16 by 55 and $161 \%$, respectively (Fig. 6).

The ability of PSP to arrest the cancer cells in the DNA synthesis S-phase (led to a higher labeling index as time of measurement) is thus our proposed mechanism on how PSP sensitized the human breast cancer ZR-75-30 cells to undergo cell death induced by the two S-phase targeting drugs Doxo and VP-16 in the present study (Fig. 6). The 'S-phase trap theory' of PSP was first observed in human leukemic HL-60 cells reported by us (16). The elevation of the DNA enzyme topoisomerase II $\alpha$ and the $\mathrm{G}_{1}$-S-phase checkpoint cyclin, cyclin E (24) measured in the PSP-treated HL-60 cells supported the interference of DNA synthesis as part of the mechanistic anticancer action of PSP.

Recent evidence indicates that PSP induces cell death of cancer cells via well defined apoptotic program $(16,22-24,47)$. When combined with the anticancer agents, the annexin V/PI flow cytometric data indicated that PSP was only able to enhance the apoptotic induction effect of Doxo and VP-16, but not Ara-C on the ZR-75-30 cells. Another interesting observation drawn from this study is that Ara-C was in fact found to be the most potent anticancer agent among the three anti-tumor agents tested alone, while Doxo was found to be the least effective in ZR-75-30 breast cancer.

This is unclear as to why PSP hinders the cytotoxic effect of Ara-C, but our data indeed reflects the importance of proper drugs selection for cancer treatment. Such antagonistic result from the combined treatment of Ara-C and PSP may be caused by the removal of the ZR-75-30 cells by PSP in the $\mathrm{G}_{1}-\mathrm{S}$ boundary, which was reported as the target phase of Ara-C $(46,48)$. Ara-C, as a pyrimidine analogue, exerts its cytotoxic action essentially by incorporation into the genome of target cells (48). Whether PSP was able to delay the cytotoxic action of Ara-C by preventing its incorporation into the DNA of the cancer cells DNA has yet to be determined.

Western blot analysis of the Bcl-2 family proteins, which are essential in modulating apoptosis (49-53), was performed to investigate the cell death mechanism of action of PSP on the ZR-75-30 cells at protein level. It has been shown that some of the breast cancer cell lines do not express Bcl-2 (54), e.g. ZR-75-1 which is a close clone of ZR-75-30. Bcl- $\mathrm{x}_{\mathrm{L}}$ has been shown to confer multi-drug resistance in several squamous cell carcinomas (52), as well as to delay apoptosis in breast cancer (53). Our results showed that the expression of Bcl-2 in ZR-75-30 is too low to be detected (Fig. 7), while $\mathrm{Bcl}-\mathrm{x}_{\mathrm{L}}$ was expressed, suggesting Bcl- $\mathrm{x}_{\mathrm{L}}$ may have taken the anti-apoptotic role of Bcl-2. Bax, on the other hand, was shown to be pro-apoptotic in various cancer cell lines (50-55), including breast cancer (56-58), and is expressed in the ZR-75-30 cells. Bid, another pro-apoptotic protein $(59,60)$, was also expressed in ZR-75-30 cells.

It is found that Bax expression (Fig. 8a) was increased to different extents under all treatments. PSP alone increased Bax protein level. Among the three chemotherapeutic drugs tested, both Ara-C and VP-16 given alone caused a significant increase in Bax expression while Doxo caused only a slight increase. However, with PSP pretreatment, the expression of Bax was further increased with Doxo and slightly increased with VP-16, while that of Ara-C was decreased. The Western blot result coincides with the cell death data analyzed by DNA/PI flow cytometry (Fig. 6), which showed that the synergistic effect was not observed in Ara-C enhanced the cell death with PSP pre-treatment. On the other hand, PSP alone and all drugs on their own decreased $\mathrm{Bcl}-\mathrm{x}_{\mathrm{L}}$ expression (Fig. 8c). With PSP pretreatment, the $\mathrm{Bcl}-\mathrm{x}_{\mathrm{L}}$ expression was further decreased to different extent. Compared with the single drug treatment groups, the $\mathrm{Bcl}-\mathrm{x}_{\mathrm{L}} / \mathrm{Bax}$ ratio was decreased in the combined treatment group (Fig. 8d). This may explain the discordance of Bax expression with cell death data, because it has been suggested that $\mathrm{Bcl}-\mathrm{x}_{\mathrm{L}} / \mathrm{Bax}$ ratio is a more important indicator of cell death $(61,62)$, and we have previously reported that the apoptotic machinery induced by PSP involves a decrease in the Bcl/Bax ratio (16). Expression of Bid, surprisingly, was suppressed in all kinds of treatments. The change of Bid expression in drugs alone comparing to drugs with PSP pretreatment is insignificant, suggesting PSP may not potentiate the cytotoxicity of Doxo, Ara-C and VP-16 in ZR-75-30 cells via modulation of Bid expression, which is one of the common ways to induce apoptosis (60).

In conclusion, the present study indicates that PSP can activate the cellular apoptotic program of Doxo and VP-16 on human breast cancer cells by creation of an S-phase trap. The data provide support for some early reports $(16,20-24)$ that PSP derived from Cov-1 strain promotes cancer cell suicide through a firmly controlled program (apoptosis). Upregulation of pro-apoptotic Bax and down-regulation of antiapoptotic $\mathrm{Bcl}-\mathrm{x}_{\mathrm{L}}$, and therefore, a decrease in $\mathrm{Bcl}-\mathrm{x}_{\mathrm{L}} / \mathrm{Bax}$ ratio was found to be associated with cell death induction synergism of mechanisms of PSP with certain chemotherapeutic drugs. Activation of the cellular apoptotic program is a current strategy for the treatment of cancers. The present study provides the first evidence to support the development of PSP as an adjuvant therapy in human breast cancer because of its ability to activate the cytotoxicity of chemotherapeutic drugs. However, the data also imply the importance of understanding its interaction with certain individual anticancer agents.

\section{Acknowledgements}

This work was partially supported by the RGC grant HKU $7511 / 03 \mathrm{M}$ of the University of Hong Kong and the Hong Kong Association for Health Care, Hong Kong, SAR, P.R. China. 


\section{References}

1. Parkin DM, Pisani P and Ferlay J: Global cancer statistics. CA Cancer J Clin 49: 33-64, 1999.

2. Greenlee RT, Murray T, Bolden S and Wingo PA: Cancer statistics, 2000. CA Cancer J Clin 50: 7-33, 2000.

3. Forbes JF: The incidence of breast cancer: the global burden, public health considerations. Semin Oncol 24: S1-20-S1-35, 1997.

4. Althuis MD, Dozier JM, Anderson WF, Devesa SS and Brinton LA: Global trends in breast cancer incidence and mortality 1973-1997. Int J Epidemiol 34: 405-412, 2005.

5. Hess KR, Pusztai L, Buzdar AU and Hortobagyi GN: Estrogen receptors and distinct patterns of breast cancer relapse. Breast Cancer Res Treat 78: 105-118, 2003.

6. Lower EE, Glass EL, Bradley DA, Blau R and Heffelfinger S: Impact of metastatic estrogen receptor and progesterone receptor status on survival. Breast Cancer Res Treat 90: 65-70, 2005.

7. Allred DC, Brown P and Medina D: The origins of estrogen receptor alpha-positive and estrogen receptor alpha-negative human breast cancer. Breast Cancer Res 6: 240-245, 2004.

8. Hussein AM, Jimenez JJ, McCall CA and Yunis AA: Protection from chemotherapy-induced alopecia in a rat model. Science 249: 1564-1566, 1990

9. Sinkule JA: Etoposide: a semisynthetic epipodophyllotoxin. Chemistry, pharmacology, pharmacokinetics, adverse effects and use as an antineoplastic agent. Pharmacotherapy 4: 61-73, 1984.

10. Sonneveld P, Mulder J and van Bekkum DW: Cytotoxicity of doxorubicin for normal hematopoietic and acute myeloid leukemia cells of the rat. Cancer Chemother Pharmacol 5: 167173,1981 .

11. Bertino JR: Approaches to selectivity in cancer chemotherapy. Adv Pathobiol 2: 65-69, 1976

12. Dow LW: Sensitivity of normal and neoplastic cells to chemotherapeutic agents in vitro. Adv Intern Med 25: 427-452, 1980 .

13. Friedlaender G.E, Tross RB, Doganis AC, Kirkwood JM and Baron R: Effects of chemotherapeutic agents on bone. I. Shortterm methotrexate and doxorubicin (adriamycin) treatment in a rat model. J Bone Joint Surg Am 66: 602-607, 1984.

14. Chao NJ, Aihara M, Blume KG and Sikic BI: Modulation of etoposide (VP-16) cytotoxicity by verapamil or cyclosporine in multidrug-resistant human leukemic cell lines and normal bone marrow. Exp Hematol 18: 1193-1198, 1990.

15. Chu E and Sartorelli AC: Cancer Chemotherapy, In: Basic and Clinical Pharmacology. Katzung BG (ed.) McGraw-Hill, pp691-715, 2005

16. Yang XT, Sit WH, Chan DK and Wan JM: The cell death process of the anticancer agent polysaccharide-peptide (PSP) in human promyelocytic leukemic HL-60 cells. Oncol Rep 13: 1201-1210, 2005.

17. Zhou YL and Yang QY: Active principles from Coriolus sp., In: Advanced Rsearch in PSP. Yang QY (ed.) Hong Kong, pp111-124, 1999.

18. Ng TB: A review of research on the protein-bound polysaccharide (polysaccharopeptide, PSP) from the mushcoom Coriolus versicolor (Basidiomycetes: Polyporaceae). Gen Pharmacol 30: 1-4, 1998.

19. Kidd PM: The use of mushroom glucans and proteoglycans in cancer treatment. Altern Med Rev 5: 4-27, 2000.

20. Hsieh TC, Kunicki J, Darzynkiewicz Z and Wu JM: Effects of extracts of Coriolus versicolor (I'm-YunityTM) on cell-cycle progression and expression of interleukin-1ß, -6 , and -8 in promyelocytic HL-60 leukemic cells and mitogenically stimulated and non-stimulated human lymphocytes. J Altern Complement Med 8: 591-602, 2002.

21. Chow LW, Lo CS, Loo WT, Hu XC and Sham JS: Polysaccharide peptide mediates apoptosis by regulating p21 gene and downregulating cyclin D1 gene. Am J Chin Med 31: 1-9, 2003.

22. Lau CBS, Ho CY, Kim CF, Leung KN, Fung KP, Tse TF, Chan HHL and Chow MSS: Cytotoxic activities of Coriolus versicolor (Yunzhi) extract on human leukemia and lymphoma cells by induction of apoptosis. Life Sci 75: 797-808, 2004

23. Ho CY, Kim CN, Leung KN, Fung KP, Tse TF, Chan H and Lau CB: Differential anti-tumor activity of Coriolus versicolor (Yunzhi) extract through p53- and/or Bcl-2-dependent apoptotic pathway in human breast cancer cells. Cancer Biol Ther 4: 638-644, 2005
24. Hui KP, Sit WH and Wan JM: Induction of S-phase cell arrest and caspase activation by polysaccharide peptide isolated from Coriolus versicolor enhanced the cell cycle dependent activity and apoptotic cell death of doxorubicin and etoposide, but not cytarabine in HL-60 cells. Oncol Rep 14: 145-155, 2005.

25. Yang QY, Jong SC, Li XY, Zhou JX, Chen RT and Xu LZ: Antitumor and immunomodulating activities of the polysaccharide-peptide (PSP) of Coriolus versicolor. J Immunol Immunopharmacol 12: 29-34, 1992.

26. Liu WK, Ng TB, Sze SF and Tsui KW: Activation of peritoneal macrophages by polysaccharopeptide from the mushroom, Coriolus versicolor. Immunopharmacology 26: 139-146, 1993.

27. Mao XW, Archambeau JO and Gridley DS: Immunotherapy with low-dose interleukin-2 and a polysaccharopeptide derived from Coriolus versicolor. Cancer Biother Radiopharm 11 393-403, 1996.

28. Qian ZM, Xu MF and Tang PL: Polysaccharide peptide (PSP) restores immunosuppression induced by cyclophosphamide in rats. Am J Chin Med 25: 27-35, 1997.

29. Wan JM, Istfan NW, Ye S-L and Bistrian BR: Insulin-like growth factor- 1 is not mitogenic for the Walker-256 Carcinosarcoma. Life Sci 56: 747-756, 1995.

30. Dolbeare F, Gratzner H, Pallavicini MG and Gray JW: Flow cytometric measurement of total DNA content and incorporated bromodeoxyuridine. Proc Natl Acad Sci USA 80: 5573-5577, 1983.

31. White RA, Terry NH and Meistrich ML: New methods for calculating kinetic properties of cells in vitro using pulse labelling with bromodeoxyuridine. Cell Tissue Kinet 23: 561-573, 1990.

32. Begg AC, McNally NJ, Shrieve DC and Karcher H: A method to measure the duration of DNA synthesis and the potential doubling time from a single sample. Cytometry 6: 620-626, 1985.

33. Fogt F, Wan JM, O'Hara C, Bistrain BR, Blackburn GL and Istfan NW: Flow cytometric measurement of cell kinetics in rat walker-256 carcinoma following in vivo and in vitro pulse labelling with bromodeoxyuridine. Cytometry 12: 33-41, 1991.

34. Shyu RY, Chang SC, Yu JC, Hsu SJ, Chou JM, Lee MS and Jiang SY: Expression and regulation of retinoid-inducible gene 1 (RIG1) in breast cancer. Anticancer Res 25: 2453-2460, 2005.

35. Engel LW, Young NA, Tralka TS, Lippman ME, O'Brien SJ and Joyce MJ: Establishment and characterization of three new continuous cell lines derived from human breast carcinomas. Cancer Res 38: 3352-3364, 1978.

36. Wan JM, Bistrian BR, Figoni MA and Istfan NW: Influence of interleukin-2 infusion on cell cycle kinetics in the Walker-256 carcinosarcoma. J Leukoc Biol 55: 241-247, 1994.

37. Koopman G, Reutelingsperger CP, Kuijten G.A, Keehnen RM, Pals ST and van Oers MH: Annexin V for flow cytometric detection of phosphatidylserine expression on B cells undergoing apoptosis. Blood 84: 1415-1420, 1994.

38. Ingle $\mathrm{J}$ : Additive hormonal therapy in women with advanced breast cancer. Cancer 53: 766-777, 1984.

39. Hussain SA, Palmer DH, Stevens A, Spooner D, Poole CJ and Rea DW: Role of chemotherapy in breast cancer. Expert Rev Anticancer Ther 5: 1095-1110, 2005

40. Namer M, Fargeot P, Roche H, Campone M, Kerbrat P, Romestaing $\mathrm{P}$, Monnier A, Luporsi E, Montcuquet $\mathrm{P}$ and Bonneterre J: Improved disease-free survival with epirubicinbased chemoendocrine adjuvant therapy compared with tamoxifen alone in one to three node-positive, estrogen-receptor-positive, postmenopausal breast cancer patients: results of French Adjuvant Study Group 02 and 07 trials. Ann Oncol 17: 65-73, 2006.

41. Fobair P, Stewart SL, Chang S, D'Onofrio C, Banks PJ and Bloom JR: Body image and sexual problems in young women with breast cancer. Psychooncology 15: 579-594, 2005.

42. Bhuyan BK, Fraser TJ, Gray LG, Kuentzel SL and Neil GL: Cell-kill kinetics of several S-phase-specific drugs. Cancer Res 33: 888-894, 1973.

43. Gohde W, Meistrich M, Meyn R, Schumann J, Johnston D and Barlogie B: Cell-cycle phase-dependence of drug-induced cycle progression delay. J Histochem Cytochem 27: 470-473, 1979.

44. Meyn RE, Meistrich ML and White RA: Cycle-dependent anticancer drug cytotoxicity in mammalian cells synchronized by centrifugal elutriation. J Natl Cancer Inst 64: 1215-1219, 1980.

45. Van Maanen JMS, Retel J, De Vries J and Pinedo HM: Mechanism of action of antitumor drug etoposide: a review. J Natl Cancer Inst 19: 1526-1533, 1988. 
46. Vial JP, Belloc F, Dumain P, Besnard S, Lacombe F, Boisseau MR, Reiffers J and Bernard P: Study of the apoptosis induced in vitro by antitumoral drugs on leukaemic cells. Leuk Res 21: 163-172, 1997.

47. Zeng F, Hon CC, Sit WH, Chow KY, Hui RK, Law IK, Ng VW, Yang XT, Leung FC and Wan JM: Molecular characterization of Coriolus versicolor PSP-induced apoptosis in human promyelotic leukemic HL-60 cells using cDNA microarray. Int $\mathbf{J}$ Oncol 27: 513-523, 2005.

48. Abdel-Aziz W, Jiang HY, Hickey RJ and Malkas LH: Ara-C affects formation of cancer cell DNA synthesome replication intermediates. Cancer Chemother Pharmacol 45: 312-319, 2000.

49. Decaudin D, Geley S, Hirsch T, Castedo M, Marchetti P, Macho A, Kofler R and Kroemer G: Bcl-2 and Bcl-XL antagonize the mitochondrial dysfunction preceding nuclear apoptosis induced by chemotherapeutic agents. Cancer Res 57: 62-67, 1997.

50. Gibson LF, Fortney J, Magro G, Ericson SG, Lynch JP and Landreth KS: Regulation of BAX and BCL-2 expression in breast cancer cells by chemotherapy. Breast Cancer Res Treat 55: 107-117, 1999.

51. Tudor G, Aguilera A, Halverson DO, Laing ND and Sausville EA: Susceptibility to drug-induced apoptosis correlates with differential modulation of Bad, $\mathrm{Bcl}-2$ and $\mathrm{Bcl}-\mathrm{xL}$ protein levels. Cell Death Differ 7: 574-586, 2000.

52. Fujita $\mathrm{N}$ and Tsuruo T: In vivo veritas: $\mathrm{Bcl}-2$ and $\mathrm{Bcl}-\mathrm{XL}$ mediate tumor cell resistance to chemotherapy. Drug Resistance Updates 3: 149-154, 2003.

53. Juin P, Geneste O, Raimbaud E and Hickman JA: Shooting at survivors: Bcl-2 family members as drug targets for cancer. Biochim Biophys Acta 1644: 251-260, 2004.

54. Anagnostopoulos GK, Stefanou D, Arkoumani E, Sakorafas G, Pavlakis G, Arvanitidis D, Tsianos E and Agnantis NJ: Bax and $\mathrm{Bcl}-2$ protein expression in gastric precancerous lesions: immunohistochemical study. J Gastroenterol Hepatol 20: 1674-1678, 2005.
55. Lin HI, Lee YJ, Chen BF, Tsai MC, Lu JL, Chou CJ and Jow GM: Involvement of Bcl-2 family, cytochrome $\mathrm{c}$ and caspase 3 in induction of apoptosis by beauvericin in human non-small cell lung cancer cells. Cancer Lett 230: 248-259, 2005.

56. Choudhuri T, Pal S, Agwarwal ML, Das T and Sa G: Curcumin induces apoptosis in human breast cancer cells through p53dependent Bax induction. FEBS Lett 512: 334-340, 2002.

57. Schiller AB, Clark WS, Cotsonis G, Lawson D, De Rose PB and Cohen C: Image cytometric bcl-2:bax and bcl-2:bcl-x ratios in invasive breast carcinoma: correlation with prognosis. Cytometry 50: 203-209, 2002.

58. Jo EH, Hong HD, Ahn NC, Jung JW, Yang SR, Park JS, Kim SH, Lee YS and Kang KS: Modulations of the Bcl-2/Bax family were involved in the chemopreventive effects of licorice root (Glycyrrhiza uralensis Fisch) in MCF-7 human breast cancer cell. J Agric Food Chem 52: 1715-1719, 2004.

59. Makin G and Dive C: Apoptosis and cancer chemotherapy. Trends Cell Biol 11: S22-S26, 2001.

60. Willis SN and Adams JM: Life in the balance: how BH3-only proteins induce apoptosis. Curr Opin Cell Biol 17: 617-625, 2005.

61. Baillat G, Garrouste F, Remacle-Bonnet M, Marvaldi J and Pommier G: Bcl-xL/Bax ratio is altered by IFN- $\gamma$ in TNF- $\alpha$ but not in TRAIL-induced apoptosis in colon cancer cell line. Biochim Biophys Acta 1745: 101-110, 2005.

62. Chang J, Hsu Y, Kuo P, Kuo Y, Chiang L and Lin C: Increase of $\mathrm{Bax} / \mathrm{Bcl}-\mathrm{XL}$ ratio and arrest of cell cycle by luteolin in immortalized human hepatoma cell line. Life Science 76: 1883-1893, 2005. 